\title{
ANALISIS SEDIMENTASI DI PELABUHAN PULAU BAAI KOTA BENGKULU
}

\author{
Putri Zilfi Hutari, Yar Johan, Bertoka Fajar Surya Perwira Negara \\ Program Studi IImu Kelautan Universitas Bengkulu \\ E-mail:putrizilfigmail.com \\ Received March 2018, Accepted April 2018
}

\begin{abstract}
ABSTRAK
Pelabuhan Pulau Baai adalah sentral ekonomi daerah yang dapat menghubungkan perpindahan muatan barang-barang produk kebutuhan sehari-hari baik dalam maupun luar Bengkulu. Sedimentasi merupakan peristiwa pengendapan material batuan yang telah diangkut oleh tenaga air atau angin. Penelitian ini bertujuan untuk mengetahui laju sedimentasi dan tekstur sedimen. Dilaksanakan pada bulan Februari - Maret 2016 di Pelabuhan Pulau Baai. Metode yang digunakan dalam melakukan penelitian ini adalah purposive sampling. 6 lokasi penelitian dipilih untuk mewakili perairan dengan beberapa parameter kualitas air. Analisis sampel sedimen dilakukan di laboraturium. Karakteristik umum perairan Pelabuhan Pulau Baai adalah temperatur $30{ }^{\circ} \mathrm{C}, \mathrm{pH}$ yang diamati adalah 7.3, salinitas berkisar $26-28 \%$, dan kecerahan $50 \%$. Analisis tekstur sedimen menggunakan segitiga shepard dan hasil yang didapatkan berupa pasir. Laju sedimentasi tertinggi terdapat di Alur Pelayaran dengan nilai $31,53 \mathrm{mg} / \mathrm{m}^{3} /$ tahun Laju sedimentasi terendah terdapat di Muara Sungai dengan nilai $0,43 \mathrm{mg} / \mathrm{m}^{3} /$ tahun.
\end{abstract}

Kata Kunci: Pelabuhan Pulau Baai, Sedimentasi, Laju Sedimentasi, Tekstur Sedimen, Kualitas Air

\begin{abstract}
Pulau Baai Port is a central of economic areas which can connected movement of necessity products, in and outside Bengkulu. Sedimentation is the deposition of rock material which have been transported by water or wind. This reaseach were to know the sedimentation rate and sediment texture. This research was conducted on February - March 2016 in Pulau Baai Harbour. The purposive sampling method was used. 6 research place was choosen to represented the waters area with some water quality parameters. Sample of sediments were analyzed at laboratory. The characteristics of Pulau Baai port waters were $30^{\circ} \mathrm{C}, \mathrm{pH}$ 7.3, salinity range $26-28 \%$, and the average of brightness $50 \%$. Analysis of sediment texture using triangles shepard and the results obtained in form of the sand, The Higher sedimentation rate was on Alur Pelayaran (31,53 mg /
\end{abstract}


$\mathrm{cm}^{2} /$ year). The lowest sedimentation rate was on Muara Sungai $(0,43 \mathrm{mg}$ $/ \mathrm{m}^{2} /$ year $)$.

Keywords: Pulau Baai Port, Sedimentation, Sedimentation Rate, Sediment Texture, Water Quality

\section{PENDAHULUAN}

Pelabuhan adalah sentral ekonomi daerah yang dapat menghubungkan perpindahan muatan barang-barang produk kebutuhan sehari-hari baik dalam negeri maupun ekspor (Triatmodjo, 1996). Keadaan pelabuhan harus diperhatikan baik dari kenyaman, keamanan dan biaya yang harus sesuai dengan kebutuhan masyarakat.

Pelabuhan Pulau Baai adalah pelabuhan vital yang dugunakan sebagai satu-satunya jalur pengangkutan laut beberapa komoditi dan barang kebutuhan pokok baik yang masuk Bengkulu maupun yang keluar (Supiyati $d k k$., 2009). Pelabuhan Pulau Baai berada sekitar $20 \mathrm{~km}$ dari pusat kota Bengkulu, dengan titik koordinat geograris $102^{\circ} 16^{\prime} 00^{\prime \prime}-102^{\circ}$ $18^{\prime} 30^{\prime \prime}$ BT dan $03^{\circ} 53^{\prime} 00^{\prime \prime}-03^{\circ} 55^{\prime} 30^{\prime \prime}$ LS dengan luas perairan luar $2.183,47$ ha dan perairan dalam 1.000 ha (Hamdani, 2013). Kendala utama pengoperasian Pelabuhan Pulau Baai adalah sedimentasi alur dan kolam dengan debit sedimen mencapai $800.000 \mathrm{~m}^{3} /$ tahun, sehingga memerlukan perawatan pengerukan secara rutin dengan biaya relatif besar (PELINDO, 2009).

Sedimentasi merupakan peristiwa pengendapan material batuan yang telah diangkut oleh tenaga air atau angin. Proses ini terjadi melalui 2 tahap, tahap pertama pada saat pengikisan, air membawa batuan mengalir ke sungai, danau, dan akhirnya sampai di laut. Tahap selanjutnya pada saat kekuatan pengangkutannya berkurang atau habis, batuan diendapkan di daerah aliran air. Hal ini juga dapat disebut sebgai transport sedimen (Rifardi, 2012).

Hartoni dan Agussalim (2007) menyebutkan bahwa transpor sedimen merupakan gerakan sedimen dari satu daerah yang disebabkan oleh gelombang dan arus yang dibangkitkannya menuju daerah lain. Selain gelombang dan arus, laju transpor sedimen juga dapat disebabkan oleh aktivitas manusia yang berada di daratan. Aktivitas penambangan di sekitar pantai mempengaruhi sebaran butiran sedimen karena aktivitas ini mensuplai Poorly Sorted Sediment (Rifardi, 2012). Lebih lanjut, transpor sedimen yang ada di pelabuhan juga dapat disebabkan karena beberapa faktor seperti arus, pasang surut, gelombang, dan aktivitas pelabuhan (Supiyati dkk., 2009).

Aktivitas pelabuhan yang sangat padat dan menjadi sentral ekonomi daerah sehingga perlu memperhatikan keadaan pelabuhan agar fungsi pelabuhan dapat dimanfaatkan dengan baik dan tidak mengganggu aktivitas lalulintas perjalanan kapal maka pemerintah secara rutin melakukan pengerukan alur pelayaran pelabuhan. Untuk menjaga kelancaran lalu lintas pelayaran di pelabuhan, salah satu faktor lingkungan 
perairan yang perlu diperhatikan adalah proses sedimentasi. Sedimentasi ini akan mengakibatkan pendangkalan yang dapat mengganggu alur transportasi dari dan menuju pelabuhan. Oleh karena itu, perlu di lakukan penelitian tentang analisis sedimentasi untuk mengetahui tekstur sedimen dan besarnya laju sedimentasi di Pelabuhan Pulau Baai. Sehingga dapat membantu pemerintah dan instansi terkait dalam menangani kendala pengoperasian di Pelabuhan Pulau Baai. Penelitian ini bertujuan untuk mengetahui laju sedimentasi di Pelabuhan Pulau Baai dan mengetahui tekstur sedimen yang ada di Pelabuhan Pulau Baai. Sehingga hasil dari penelitian ini dapat menginformasikan laju sedimentasi di Pelabuhan Pulau Baai dan menjadi acuan bagi instansi terkait dalam menangani masalah sedimentasi yang terjadi di Pelabuhan Pulau baai

\section{MATERI DAN METODE}

\section{Waktu dan Tempat Penelitian}

Penelitian ini dilaksanakan pada bulan Februari sampai dengan bulan Maret 2016 di wilayah Pelabuhan Pulau Baai, Kota Bengkulu (Lihat Gambar 1) dengan koordinat lokasi penelitian (Lihat Tabel 1).
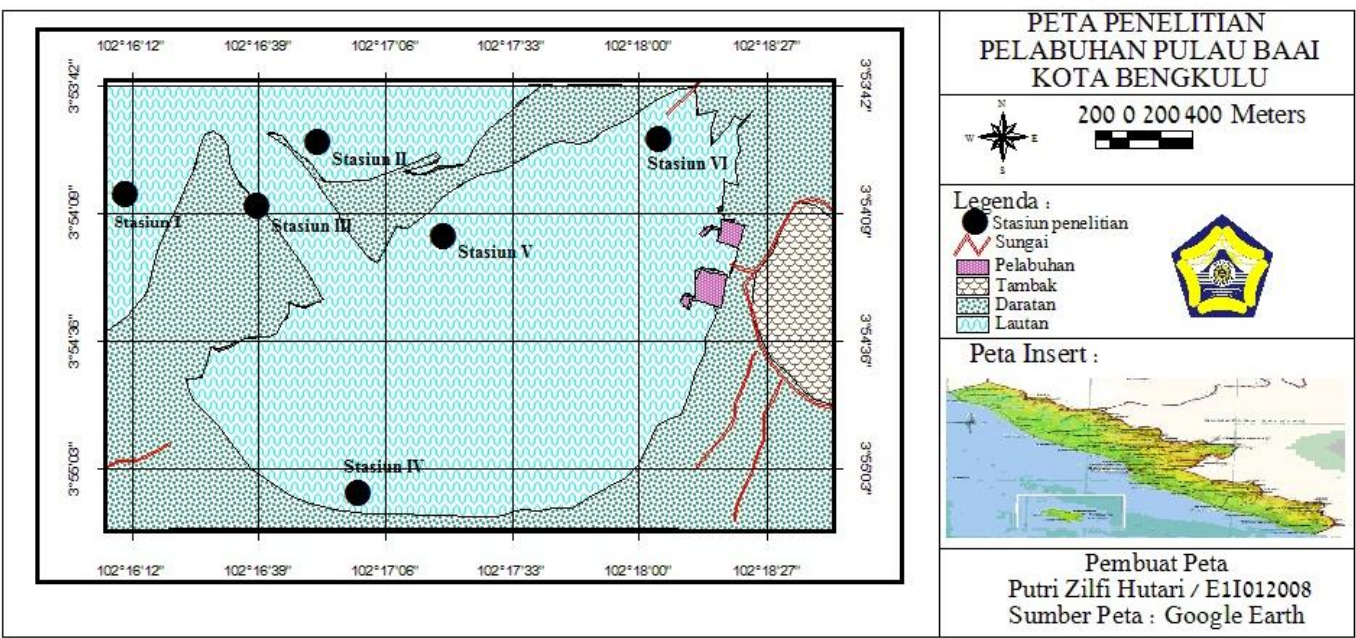

Gambar 1. Lokasi penelitian

Tabel 1. Lokasi Koordinat Penelitian

\begin{tabular}{lll}
\hline \multirow{2}{*}{ Lokasi Penelitian } & \multicolumn{2}{l}{ Titik Koordinat } \\
\cline { 2 - 3 } & Longitude & Latitude \\
\hline Stasiun I & 102.271587 & 03.901928 \\
Stasiun II & 102.283166 & 03.898969 \\
Stasiun III & 102.278740 & 03.902849 \\
Stasiun IV & 102.284149 & 03.919602 \\
\hline
\end{tabular}




\begin{tabular}{lll}
\hline Stasiun V & 102.288870 & 03.905120 \\
Stasiun VI & 102.301660 & 03.898683 \\
\hline
\end{tabular}

\section{Alat dan Bahan}

Alat dan bahan penelitian diantara adalah GPS, Thermometer, Refraktometer, pH Meter, Secchi Disk, Roll meter, Oven, Alumunium Foil, Saringan Bertingkat, Timbangan analitik, Plastik, Kertas Label, Nampan Aluminium, Alat tulis, Sediment trap, Perahu nelayan, dan Cawan Petri.

\section{Teknik Pengambilan Sampel}

Lokasi sampling pada penelitian ini mempunyai hal - hal yang perlu diperhatikan dalam pemilihan lokasi sampling antara lain topografi, karakteristik, pola arus dan morfologi perairan pelabuhan demi kemudahan dalam melakukan sampling. Lokasi sampling ditentukan di 6 titik yang mewakili seluruh sampel yang dibutuhkan.

\section{Data Sedimen}

Pengambilan sampel sedimen dilakukan dengan menggunakan sediment trap yang diletakkan di dasar perairan sesuai dengan lokasi yang telah ditentukan. Sediment trap terbuat dari 3 pipa PVC dengan ukuran masing-masing diameter $8 \mathrm{~cm}$ dan tinggi $27 \mathrm{~cm} \mathrm{~cm}$ pada bagian atas memiliki skat-sekat (baffles) penutup, tabung perangkap sedimen dipasang pada tiang besi dengan ketinggian $52 \mathrm{~cm}$ dari dasar dengan pemberat menggunakan campuran semen, pasir dan kerikil (Rifardi, 2008) (Gambar 2). Sediment trap ditinggal selama 21 hari dan diambil setiap 7 hari sekali, setelah itu sampel sedimen yang berada di dalam sediment trap diambil yang kemudian dikeringkan dalam oven pada suhu $60{ }^{\circ} \mathrm{C}$ selama 27 jam (English et al., 1997) lalu dianalisa jenis tekstur sedimen dan ditimbang untuk mengetahui laju sedimentasinya di laboratorium.

\section{Analisa Data \\ Analisis Pengukuran Tekstur Sedimen}

Penentuan tekstur sedimen dilakukan dengan menggunakan saringan bertingkat (sieving) untuk fraksi pasir kemudian ditimbang berdasarkan ukuran diameter butiran sedimen. Untuk menentukan ukuran butir sedimen berdasarkan Skala Wentworth (Wibisono, 2005). Selanjutnya data komposisi sedimen berdasarkan ukuran butir diolah menggunakan segitiga.

\section{Analisis Laju Sedimentasi}

Laju sedimentasi dinyatakan dalam $\mathrm{mg} / \mathrm{cm}^{2} /$ hari (Roger et al. 1994 dalam Barus, 2013). Pengamatan dilakukan dengan mengambil sedimen 
yang terperangkap dalam sediment traps yang dipasang selama 21 hari. Selanjutnya dihitung berat kering sedimen (dalam $\mathrm{mg}$ ) dengan menggunakan timbangan analitik.

\section{HASIL DAN PEMBAHASAN}

\section{Gambaran Umum Pelabuhan Pulau Baai}

Pelabuhan Pulau Baai adalah satu - satunya pelabuhan yang terletak di Kota Bengkulu dan berhadapan langsung dengan Samudera Hindia yang terletak di Kecamatan Selebar Kota Bengkulu, berada di posisi $03^{\circ} 47^{\prime} 30^{\prime \prime}$ LS dan $102^{\circ} 15^{\prime} 04^{\prime \prime}$ BT.

Pelabuhan Bengkulu sebelum berada di Pulau Baai berlokasi di Tapak Paderi, dikarenkan kondisi yang tidak memungkinkan untuk dilakukan pengembangan area pelabuhan maka dipilihlah lokasi Pulau Baai sebagai area kolam pelabuhan. Pemilihan area Pulau Baai sebagai daerah baru untuk kolam pelabuhan tidak terlepas dari kondisi geografis yang baik untuk dijadikan area kolam pelabuhan karena memiliki kolam labuh yang besar dan merupakan lokasi terbaik yang tersedia di area Bengkulu, namun di area alur pelayaran terdapat masalah yakni transport sedimen yang besar sehingga perlu dilakukan perawatan secara berkala. Panjang breakwater sebelah kiri $652 \mathrm{~m}$ dengan lebar $6 \mathrm{~m}$, sebelah kanan panjang $2.300 \mathrm{~m}$ dengan lebar $6 \mathrm{~m}$.

Pola umum arus di pelabuhan Pulau Baai pada saat surut menuju pasang arus menuju ke arah timur, dan pada waktu air pasang menuju surut arus menuju arus ke arah barat daya. Kecepatan arus yang keluar lebih kecil, maka sedimen yang masuk tidak ikut terbawa semua ke luar sehingga terjadi pengendapan sedimen di kolam pelabuhan. Pengendapan sedimen juga terjadi di luar kolam bagian barat dan mulut alur bagian luar, sedangkan di luar kolam bagian timur terjadi erosi (Supiyati $d k k ., 2012$ ).

\section{Analisis Kualitas Air}

Pengukuran parameter kualitas air dilakukan secara in situ pada penelitian ini meliputi temperatur, $\mathrm{pH}$, salinitas dan kecerahan, dapat dilihat pada Tabel 2.

Tabel 2. Parameter Kualitas Air

\begin{tabular}{llllll}
\hline $\begin{array}{c}\text { Lokasi } \\
\text { Penelitian }\end{array}$ & $\begin{array}{c}\text { Temperatur } \\
\left({ }^{\circ} \mathbf{C}\right)\end{array}$ & $\begin{array}{c}\text { Palinitas } \\
(\mathbf{\%} \% \mathbf{o o})\end{array}$ & $\mathbf{p H}$ & $\begin{array}{c}\text { Kecerahan } \\
\mathbf{( \% )}\end{array}$ & $\begin{array}{c}\text { Kedalaman } \\
(\mathbf{m})\end{array}$ \\
\hline Stasiun I & 28,50 & 28,00 & 7,40 & 53,00 & 7 \\
Stasiun II & 28,25 & 27,75 & 7,30 & 21,00 & 16 \\
Stasiun III & 29,75 & 28,00 & 7,30 & 25,00 & 10 \\
Stasiun IV & 32,00 & 28,50 & 7,40 & 60,00 & 2.5 \\
Stasiun V & 32,00 & 28,50 & 7,40 & 62,00 & 2 \\
Stasiun VI & 30,00 & 27,50 & 7,00 & 77,00 & 2 \\
\hline
\end{tabular}




\section{Analisis Pengukuran Tekstur Sedimen}

Hasil analisis sampel sedimen dari 6 lokasi penelitian yang diletakkan pada sedimen trap selama 21 hari dan diambil 7 hari sekali, maka didapatkan hasil jenis sedimen yang terdapat pada lokasi penelitian menunjukan pada Tabel 3.

Tabel 3. Nilai hasil analisis tekstur sedimen Pelabuhan Pulau Baai Bengkulu.

\begin{tabular}{lllll}
\hline No & \multicolumn{1}{c}{ Stasiun } & $\begin{array}{c}\text { Pasir (sand) } \\
\%\end{array}$ & $\begin{array}{c}\text { Lanau (silt) } \\
\%\end{array}$ & $\begin{array}{c}\text { Jenis } \\
\text { Sedimen }\end{array}$ \\
\hline 1 & Stasiun I & 99,80 & 0,20 & Pasir \\
2 & Stasiun II & 99,70 & 0,30 & Pasir \\
3 & Stasiun III & 99,80 & 0,20 & Pasir \\
4 & Stasiun IV & 99,70 & 0,30 & Pasir \\
5 & Stasiun V & 86,80 & 13,20 & Pasir \\
6 & Stasiun VI & 93,00 & 7,00 & Pasir \\
\hline
\end{tabular}

Stasiun I terletak di sebelah kiri Pelabuhan Pulau Baai dengan koordinat $102^{\circ} 16^{\prime} 17.71^{\prime \prime}$ BT dan $3^{\circ} 54^{\prime} 6.94^{\prime \prime}$ LS. Daerah ini merupakan daerah yang terjadi sedimentasi (Hamdani, 2013). Nilai hasil analisis tekstur sedimen pada stasiun I terdapat pasir $99,80 \%$ dan lanau 0,20\% (Tabel 3). Menentukan tekstur sedimen menggunkan segitiga shepard sehingga didapatkan tekstur sedimen adalah pasir. Persentase hasil tekstur sedimen Pelabuhan Pulau Baai dari 3 kali pengulangan di dapatkan fraksi yang paling dominan adalah fraksi pasir dan jenis tekstur sedimen pasir.

Dahuri et al. (2001) dalam Wibowo (2012) menyatakan bahwa gelombang yang pecah di daerah pantai merupakan salah satu penyebab utama terjadinya proses erosi dan sedimentasi di pantai. Gelombang yang menimbulkan terjadinya arus menyusur pantai adalah penyebab utama dari gerakan sedimen (Komar, 1983). Arus yang terjadi di Pelabuhan Pulau Baai adalah arus menyusur pantai merupakan pergerakan massa air yang bergerak sejajar dengan garis pantai (Triadmodjo, 1999). Pengaruh arus terhadap sedimentasi dipengaruhi ukuran partikel sedimen, semakin besar partikel yang diendapkan maka pengaruh arus laut akan semakin besar. Hal ini berarti tempat mengendap partikel yang lebih kecil terletak dari titik sumber dari mana partikel tersebut berasal.

Hasil analisis tekstur sedimen yang terdapat stasiun II berjenis pasir dengan persentase pasir 99,70\% dan lanau 0,30\% (Tabel 3). Koordinat pada lokasi ini $102^{\circ} 16^{\prime} 59.40^{\prime \prime}$ BT dan $3^{\circ} 53^{\prime} 56.29^{\prime \prime}$ LS. Secara umum sedimen permukaan daerah penelitian disusun oleh beberapa kelas ukuran sedimen. Fraksi butiran merupakan fraksi sedimen yang hanya sedikit terdapat di perairan pelabuhan dengan ukuran $2-4 \mathrm{~mm}$. Hal ini diduga disebabkan oleh tidak adanya sumber sedimen yang berfraksi batuan yang begitu banyak karena karakter dasar perairan pelabuhan disusun oleh fraksi pasir dan tanah liat (lanau) (Febriyani, 2013). 
Lokasi stasiun II tergolong terbuka terhadap arah tiupan angin, sehingga hempasan gelombang cukup kuat. Hempasan gelombang akan menyebabkan abrasi atau erosi pantai, sehingga garis pantai mundur ke arah darat (Purba, 2003). Material yang digerus oleh hempasan gelombang akan dipindahkan sebagian besar oleh arus menyusur pantai sepanjang pantai. Sedimen yang digerus oleh gelombang pada lokasi tertentu akan diangkut oleh arus menyusur pantai dan diendapkan pada lokasi dimana energi gerak air melemah (Sulistyo, 1994). Dahulunya sebelum dibuat Pelabuhan, kolam Pulau Baai terdapat lidah pasir yang yang membujur dari arah selatan ke utara. Lidah pasir ini terbentuk oleh angkutan pasir dari sebelah hulu Tanjung Kerbau (Hamdani, 2013).

Stasiun III merupakan tempat keluar masuknya transportasi laut dengan koordinat $102^{\circ} 16^{\prime} 43.46^{\prime \prime}$ BT dan $3^{\circ} 54^{\prime} 10.26^{\prime \prime}$ LS stasiun ini terletak di dekat breakwater. Nilai analisis tekstur sedimen yang terdapat di alur pelayaran dengan persentase pasir $99,8 \%$ dan lanau 0,2 \% dan tekstur yang didapatkan berjenis pasir (Tabel 3). Proporsi pasir berkisar $90 \%$ dan hampir merata tersebar disetiap stasiun terdapat pasir halus yang memiliki proposi yang paling dominan. Selain disebabkan karakteristik perairan yang berpasir, gelombang, arus dan pasang surut juga mempengaruhi dalam mentranspor sedimen (Supiyati $d k k$., 2012).

Sebaran fraksi yang terdapat di alur pelayaran dominan pasir halus, dikarenakan pergerakan arus yang melemah saat keluar dari kolam menuju laut lepas. Arus pasang surut di Pelabuhan Pulau Baai membawa partikel-partikel dari laut lepas menuju kolam pelabuhan dengan kecepatan sekitar 0,1 - 0,13 $\mathrm{m} / \mathrm{s}$ (Supiyati $d k k, 2012$ ) sedangkan di dalam kolam kecepatan arus pasang surut sekitar 0,001-0,005 m/s. Partikel yang terbawa dari laut lepas tidak mampu keluar lagi sehingga terjadi penumpukan partikel yang disebut dengan sedimentasi. Partikel - partikel yang terbawa dari laut lepas ini yang paling dominan adalah fraksi pasir dengan ukuran 0,125 mm. Hal yang sesuai dikatakan Febriyani (2013) mengatakan diameter sedimen di belakang breakwater cenderung lebih halus karena letaknya terlindung oleh breakwater dan sedikt mendapatkan pengaruh dari gelombang laut.

Stasiun IV yang berkoordinat $102^{\circ} 17^{\prime} 2.94^{\prime \prime}$ BT dan $3^{\circ} 55^{\prime} 10.57^{\prime \prime}$ LS terdapat didekat pelabuhan batubara. Persentase pasir pada lokasi ini adalah 99,30\% dan lanau 0,70\% dengan tekstur sedimen pasir (Tabel 3). Sebaran fraksi yang dominan di lokasi ini adalah fraksi pasir kasar diduga partikel sedimen berasal dari limbah batubara. Analisis tekstur yang dilakukan di Laboraturium Perikanan Fakultas Pertanian Universitas Bengkulu fraksi yang paling banyak di lokasi ini adalah limbah batubara.

Aktivitas manusia di sekitar pantai mempengaruhi sebaran butiran sedimen karena aktivitas ini mensuplai Poorly Sorted Sediment (Rifardi, 2012). Poorly Sorted Sediment merupakan perbedaan besar butir yang cukup mencolok, sehingga partikel yang dianalisis besaran butirnya dapat dilihat secara visual.

Stasiun $\mathrm{V}$ ini merupakan lokasi penelitian yang berada di depan ekosistem mngrove dengan koordinat $102^{\circ} 17^{\prime} 19.93^{\prime \prime}$ BT dan $3^{\circ} 54^{\prime} 18.43^{\prime \prime}$ 
LS. Persentase pasir $86,80 \%$ dan lanau $13,20 \%$ dengan tekstur sedimen pasir (Tabel 3). Ekosistem mangrove merupakan ekosistem yang terdapat di daerah pantai yang secara teratur tergenang air laut dan terpengaruh oleh pasang surut air laut tetapi tidak terpengaruh oleh iklim. Perakaran mangrove dapat mengakumulasi sedimen, merangkap serasah, dan berperan dalam pembentukan formasi tanah (Kennish, 2000).

Persentase pasir pada stasiun ini yang dekat dengan muara sungai adalah $93,00 \%$ dan lanau $7,00 \%$. Dengan koordinat $102^{\circ} 18^{\prime} 5.98^{\prime \prime}$ BT dan $3^{\circ} 50^{\prime} 55.26$ " LS, tekstur sedimen pada muara sungai berjenis pasir (Tabel 3). Sebaran fraksi yang dominan di muara sungai adalah fraksi sedang. Fraksi sedang terdapat di muara sungai yang merupakan lokasi yang dekat dengan muara sungai dan sebaran sedimen tergantung pada pola arus dasar perairan (Daulay, 2014).

\section{Fraksi Sedimen}

Fraksi sedimen yang dominan di setiap stasiun penelitian adalah fraksi pasir halus. Pada stasiun I, II, III dan V fraksi sedimen diklasifikasikan dalam pasir halus, Stasiun IV fraksi sedimen yang dianalisis adalah pasir kasar. Sedangkan satsiun VI fraksi sedimen pasir sedang (Tabel 4).

Tabel 4. Fraksi Sedimen Dominan Setiap Lokasi Penelitian

\begin{tabular}{llll}
\hline No & Lokasi Penelitian & \multicolumn{1}{c}{ Fraksi Sedimen } & Ukuran $\mathbf{( m m})$ \\
\hline 1 & Stasiun I & Pasir Halus & 0,125 \\
2 & StasiunII & Pasir Halus & 0,125 \\
3 & Stasiun III & Pasir Halus & 0,125 \\
4 & Stasiun IV & Pasir Kasar & 0,600 \\
5 & Stasiun V & Pasir Halus & 0,125 \\
6 & Stasiun VI & Pasir Sedang & 0,300 \\
\hline
\end{tabular}

Pasir halus diduga berasal dari laut lepas, pasir halus masuk ke dalam kolam pelabuhan dipengaruhi oleh arus gelombang menyusur pantai. Hal yang sama dengan pernyataan Febriyani (2013) kecepatan arus yang menjadi penentu transpor sedimen dasar dan partikel material yang terangkut. Mulyadi $d k k$, (2013) laut lepas memiliki kecepatan arus kuat cenderung memiliki sebaran fraksi pasir. Pasir kasar terdapat di pengankutan batubara, pada analisis tekstur sedimen yang dilakukan di Laboraturim Perikanan Program Studi IImu Kelautan Universitas Bengkulu, fraksi sedimen yang terdapat di lokasi ini partikel - partikelnya berupa limbah batubara. Diduga fraksi kasar berasal dari pengangkutan batubara yang terjatuh ke perairan. Fraksi sedang terdapat di muara sungai yang merupakan lokasi yang dekat dengan muara sungai. Sebaran sedimen tergantung pada pola arus dasar perairan (Daulay, 2014).

Partikel sedimen halus yang ditemukan di lokasi penelitian di stasiun I, II, III dan V, ukuran butir sedimen halus mengindikasikan kekuatan arus lemah untuk menstrapor sedimen, begitu juga sebaliknya, 
arus yang kuat mengindikasikan butir sedimen kasar (Rifardi dan Ujiie, 1993). Stasiun V dengan kecepatan arus yang lemah didapatkan fraksi kasar hal ini berbanding terbalik dengan pernyatan Rifardi et al (1998) menyatakan pearairan dengan kecepatan arus kuat dicirikan oleh ukuran partikel sedimen kasar, merupakan indikasi besar/kuatnya kekuatan arus dan gelombang yang bekerja pada lingkungan pengendapan tersebut. Pasir kasar yang terdapat di stasiun $V$ ini berasal dari pengangkutan batubara yang teletak didekat lokasi penelitian, pada stasiun $\mathrm{V}$ tidak ada pengaruh arus dari pantai, sehingga sedimen pada lokasi ini hanya sedikit.

Stasiun VI yang terletak di muara sungai fraksi yang paling dominan adalah fraksi sedang. Muara sungai fraksi yang paling dominan adalah lumpur karena adanya suplai partikel dari sungai, akan tetapi pada stasiun VI ini yang paling dominan adalah pasir sedang. Hal ini disebabkan suplai sedimen dari sungai tidak terlalu dekat dengan stasiun penelitian, pada lokasi ini masih adanya vegetasi pantai sehingga partikel yang terperangkap di sedimen trap masih berasal dari pantai itu sendiri. Stasiun ini juga masih berdekatan dengan aktivitas manusia seperti adanya alat tangkap sero di dekat stasiun penelitian.

Sebaran partikel di lokasi penelitian yang mendominan adalah pasir halus, sedimentasi dalam skala yang kecil dapat terjadi karena transportasi sedimen sepanjang pantai (Ridho, 2005) sehingga diduga partikel sedimen berasal dari pantai tersebut.

\section{Analisis Laju Sedimentasi}

Hasil analisis sampel sedimen yang terperangkap dan kemudian dikeringkan di oven dengan suhu $60{ }^{\circ} \mathrm{C}$ selama 27 jam (sampai berat sampel konstan). Berat sampel dihitung menggunakan rumus dan menghasilkan laju sedimentasi per hari yang tercantum pada Tabel 5.

Tabel 5. Laju Sedimentasi Disetiap Lokasi Penelitian.

\begin{tabular}{ll}
\hline Lokasi Penelitian & Laju Sedimentasi $\left(\mathbf{m g} / \mathbf{c m}^{2} / \mathbf{h a r i}\right)$ \\
\hline Stasiun I & $1.501,20$ \\
Stasiun II & 840,04 \\
Stasiun III & $2.879,56$ \\
Stasiun IV & 761,90 \\
Stasiun V & 70,37 \\
Stasiun VI & 39,70 \\
\hline
\end{tabular}

Pengamatan laju sedimentasi dilakukan 6 lokasi penelitian pada 21 hari dengan pengambilan 7 hari sekali, dimana waktu peletakan sedimen trap pada tanggal 14 Februari 2016 dan pengambilan sampel dimulai pada tanggal 21 Februari 2016 dan diakhiri tanggal 6 Maret 2016. Laju sedimentasi ditampilkan dalam rata-rata laju sedimentasi tiap titik selama 21 hari. Hasil laju sedimentasi tersebut dapat dilihat dalam Tabel 6. 
Hasil pengamatan laju sedimentasi yang terbesar terdapat pada stasiun I dan stasiun III. Stasiun I terletak di luar sebelah kiri mulut pelabuhan dengan laju sedimentasi $1.501,20 \mathrm{mg} / \mathrm{cm}^{2} /$ hari (Tabel 6) dengan temperatur perairan $28{ }^{\circ} \mathrm{C}$, salinitas $28 \%$ oo, $\mathrm{pH} 7,4$ dan kecerahan $53 \%$, parameter kualitas air mempengaruhi proses pengendapan temperatur yang rendah akan mempercepat pengendapan, hal ini sesuai dengan pernyataan Daulay (2014) mengatakan stasiun yang yang memiliki temperatur tinggi saat pengukuran akan memiliki kondisi pengendapan yang lebih rendah daripada lokasi yang memilki temperatur yang lebih rendah. Kedalaman pada stasiun I yakni $7 \mathrm{~m}$, kedalaman mempengaruhi kecepatan pengendapan. Semakin besar partikel yang akan terjadi maka semakin besar pula kecepatan jatuh sedimen (Supiyati, 2013).

Tabel 6. Hasil Perhitungan Laju Sedimentasi di stasiun I.

\begin{tabular}{llll}
\hline Lokasi & \multicolumn{3}{l}{ Berat Sampel Kering $(\mathbf{m g})$} \\
Penelitian & $\mathbf{1}$ & $\mathbf{2}$ & $\mathbf{3}$ \\
\hline $\begin{array}{l}\text { Stasiun I } \\
\text { Laju Sedimentasi } \\
\left(\mathrm{mg} / \mathrm{cm}^{2} / \text { hari) }\right.\end{array}$ & 917,92 & 715,33 & 742,49 \\
\hline
\end{tabular}

Stasiun I memilki dampak terjadinya pendangkalan, lokasi ini terdapat di Pantai Teluk Sepang dengan kecepatan arus sekitar $0,13 \mathrm{~m} / \mathrm{s}$ yang berasal dari arah barat laut yang memutar balik ke arah timur atau mulai bergerak dari laut lepas menuju kolam pelabuhan (Supiyati, $d k k$. 2012).

Stasiun II ini terletak di luar sebelah kanan mulut pelabuhan disebut juga Pantai Lentera Merah dengan laju sedimentasi $840,04 \mathrm{mg} / \mathrm{cm}^{2} /$ hari (Tabel 7). Temperatur perairan $28{ }^{\circ} \mathrm{C}$, salinitas $27 \%$, pH 7,3 dan kecerahan 21\%, menurut Rifardi (2012) menyatakan bahwa pH mempengaruhi proses pelarutan partikel-partikel sedimen. Apabila $\mathrm{pH}$ perairan tinggi maka dalam kondisi ini hampir tidak terjadi proses pelarutan partikel-partikel sedimen. Kedalaman pada stasiun II berkisar 16 $\mathrm{m}$ terletak di Pantai Lentera Merah dengan tingkat dampak daerah yang relatif aman, partikel yang jatuh dalam sedimen trap merupakan pasir halus. Pasir halus berasal dari pantai itu sendiri dengan adanya gelombang menyusur pantai.

Tabel 7. Hasil Perhitungan Laju Sedimentasi di Stasiun II.

\begin{tabular}{lccc}
\hline \multicolumn{1}{c}{ Lokasi Penelitian } & \multicolumn{3}{c}{$\begin{array}{c}\text { Berat Sampel Kering (mg) } \\
2\end{array}$} \\
\hline $\begin{array}{l}\text { Stasin II } \\
\begin{array}{l}\text { Laju Sedimentasi } \\
\text { (mg/cm²/hari) }\end{array}\end{array}$ & 351,08 & 462,54 & 515,80 \\
\hline
\end{tabular}


Lokasi penelitian ini memiliki kecepatan arus sekitar $0,11 \mathrm{~m} / \mathrm{s}$ (Supiyati, dkk. 2012). Sedimen yang digerus oleh gelombang pada lokasi tertentu akan diangkut oleh arus menyusur pantai dan diendapkan pada lokasi dimana energi gerak air melemah (Sulistyo, 1994).

Stasiun III terletak di mulut pelayaran sebelah kiri dengan laju sedimentasi $2.879,56 \mathrm{mg} / \mathrm{cm}^{2} /$ hari (Tabel 8) dengan kedalaman perairan $10 \mathrm{~m}$. Stasiun ini merupakan laju sedimentasi yang paling besar, hal ini sesuai dengan penelitian Supiyati $d k k$, (2012) menyatakan bahwa sedimentasi terjadi di mulut alur bagian luar diakibatkan oleh arus yang keluar dari kolam pelabuhan kecepatannya tidak cukup besar untuk membawa sedimen ke laut lepas kembali. Hal ini mengakibatkan sedimen tertahan dan terjadi penumpukan, kondisi perairan di lokasi penelitian ini yakni temperatur $29^{\circ} \mathrm{C}$, salinitas $28 \%$, pH 7,3 dan kecerahan $25 \%$. Temperatur yang tinggi akan memperlambat endapan partikel, karena partikel akan bergerak aktif. Pada stasiun III laju sedimentasinya tinggi dengan suhu tinggi, hal ini disebabkan adanya pergerakan air yang melemah dan partikel tertahan di breakwater.

Tabel 8. Hasil Perhitungan Laju Sedimentasi di Stasiun III.

\begin{tabular}{lrcc}
\hline \multicolumn{1}{c}{ Stasiun } & \multicolumn{3}{c}{ Berat Sampel Kering $(\mathrm{mg})$} \\
\multicolumn{1}{c}{\begin{tabular}{c}
\multicolumn{1}{c}{ Stasiun III } \\
Laju Sedimentasi \\
$\left(\mathrm{mg} / \mathrm{cm}^{2} /\right.$ hari $)$
\end{tabular}} & $1.574,98$ & $1.496,900$ & 3 \\
\hline
\end{tabular}

Stasiun III berpotensi terjadinya pendangkalan. Hal ini sesuai dengan pernyataan Pelindo II (2009) bahwa pendangkalan perairan yang menjadi kendala pengoperasian transportasi laut, yang selama ini terjadi di Pelabuhan Pulau Baai. Sehingga perlu dilakukan perawatan setiap tahunnya. Penanganan sedimentasi yang terjadi di Pelabuhan Pulau Baai Kota Bengkulu telah banyak dilakukan, seperti menggunakan metode kapal keruk. Metode ini sangat efektif tetapi tidak efisien karena biaya yang diperlukan mencapai Rp. 28 - 30 milyar rupiah pertahun (Supiyati dkk., 2009).

Menurut Hamdani (2013) menyatakan bahwa ada beberapa cara dalam mengatasi endapan pasir yang terjadi di Pelabuhan Pulau Baai, salah satunya adalah metode tower crane. Metode tower crane ini biasanya digunakan pada bangunan bertingkat yang tinggi, jalan tol dan industri perkayuan.

Stasiun IV terletak didekat pengangkutan batubara dengan laju sedimentasi $761,90 \mathrm{mg} / \mathrm{cm}^{2} /$ hari (Tabel 9) dengan kedalaman 2,5 m. Hasil penelitian analisis tekstur sedimen di stasiun ini terdapat partikel - partikel dari limbah batubara yang masuk dalam kategori fraksi pasir kasar. Biasanya fraksi kasar dapat menyebabkan sedimentasi yang paling besar karena pergerakan partikel yang mengendap terlebih dahulu adalah fraksi yang besar. Namun berbeda pada stasiun ini dimana fraksi kasar diduga 
dari limbah batubara dan arus yang ada di kolam menurut Supiyati, dkk. (2012) kecepatan arusnya $0,001 \mathrm{~m} / \mathrm{s}$, sehingga partikel yang berasal dari laut lepas masuk ke kolam diputar kembali untuk keluar menuju laut lepas, adanya pergerakan air yang melemah sehingga partikel tertahan di belakang breakwater. Sedimen yang ada di stasiun ini hanya sedikit yang terperangkap dalam sedimen trap. Stasiun ini termasuk dalam tingkat dampak daerah relatif aman, sedimen berasal dari aktivitas pengangkutan batubara yang berada pada lokasi penelitian.

Tabel 9. Hasil Perhitungan Laju Sedimentasi di Stasiun IV

\begin{tabular}{lccc}
\hline \multicolumn{1}{c}{ Stasiun } & \multicolumn{3}{c}{ Berat Sampel Kering $(\mathrm{mg})$} \\
& 1 & 2 & 3 \\
\hline $\begin{array}{l}\text { Stasiun IV } \\
\text { Laju Sedimentasi } \\
\left(\mathrm{mg} / \mathrm{cm}^{2} / \text { hari) }\right.\end{array}$ & 433,59 & 456,47 & 315,70 \\
\hline
\end{tabular}

Aktivitas manusia di sekitar pantai mempengaruhi sebaran butiran sedimen karena aktivitas ini mensuplai Poorly Sorted Sediment (Rifardi, 2012). Poorly Sorted Sediment merupakan perbedaan besar butir yang cukup mencolok. Stasiun $\mathrm{V}$ memiliki temperatur $32^{\circ} \mathrm{C}$, Salinitas $28,5 \%$, pH 7,4 dan kecerahan $60 \%$. Kecerahan tinggi pada stasiun ini tidak terlalu banyaknya partikel yang tersuspensi di stasiun ini.

Stasiun $\mathrm{V}$ terletak didepan ekosistem mangrove dengan laju sedimentasi $70,37 \mathrm{mg} / \mathrm{cm}^{2} /$ hari (Tabel 10) dengan kedalaman $2 \mathrm{~m}$, temperatur pada stasiun ini $32^{\circ} \mathrm{C}$, salinitas $28,5 \%$, pH 7,4, dan kecerahan $62 \%$. Lokasi ini laju sedimentasinya rendah, ini dikarenakan salah satu fungsi dari mangrove adalah perakaran mangrove dapat mengakumulasi sedimen, menangkap serasah, dan berperan dalam pembentukan formasi tanah (Kennish, 2000). Faktor lainnya temperatur yang tinggi yang mempengaruhi lambatnya pergerakan partikel yang jatuh.

Tabel 10. Hasil Perhitungan Laju Sedimentasi di Stasiun V

\begin{tabular}{lcccc}
\hline \multirow{2}{*}{ Lokasi Penelitian } & & \multicolumn{3}{c}{ Berat Sampel Kering $(\mathrm{mg})$} \\
& & 2 & 3 \\
\hline Stasiun V & 30,59 & 42,98 & 37,80 & \\
Laju Sedimentasi & 70,37 & & & \\
(mg/cm $\mathrm{m}^{2} /$ hari) & & & & \\
\hline
\end{tabular}

Dampak laju sedimentasi dapat mengakibatkan pendangkalan. Diduga partikel sedimen yang terbawa oleh arus dibawa kembali ke arah alur pelayaran dan pergerakkan air melemah di daerah breakwater sehingga terjadinya penumpukan di lokasi alur pelayaran.

Stasiun VI dekat dengan sungai dengan laju sedimentasi 39,70 $\mathrm{mg} / \mathrm{cm}^{2} /$ hari (Tabel 11 ) dengan kedalaman $2 \mathrm{~m}$, muara sungai laju sedimentasinya paling rendah karena pada stasiun ini terletak pada 
daerah yang masih memiliki vegetasi hal ini sesuai dengan pernyataan Daulay (2014) menyatakan bahwa pengendapan akan terus meningkat apabila kondisi vegetasi pada suatu daerah tidak dijaga, pada lokasi ini masih banyak vegetasi disekitar stasiun sehingga partikel-partikel dapat diakumulasikan oleh vegetasi di muara sungai. Temperatur pada stasiun $\mathrm{VI}$ yakni $30^{\circ} \mathrm{C}$, salinitas $27,5 \%$, $\mathrm{pH} 7$ dan kecerahan $77 \%$.

Tabel 11. Hasil Perhitungan Laju Sedimentasi di Stasiun VI

\begin{tabular}{llcc}
\hline \multirow{2}{*}{ Lokasi Penelitian } & \multicolumn{3}{c}{ Berat Sampel Kering $(\mathrm{mg})$} \\
& 1 & 2 & 3 \\
\hline $\begin{array}{l}\text { Stasiun VI } \\
\text { Laju Sedimentasi } \\
\left(\mathrm{mg} / \mathrm{cm}^{2} / \text { hari) }\right.\end{array}$ & 12,380 & 26,750 & 23,700 \\
\hline
\end{tabular}

Salah satu faktor yang mempengaruhi sedimentasi adalah debit aliran. Selama aliran rendah angkutan sedimen bisa jadi sedikit sedangkan pada saat aliran tinggi sungai bisa mengangkut muatan sedimen yang tinggi dengan ukuran sedimen dalam jangka yang lebih luas, namun kenyataannya debit aliran sungai yang mengalir sangat bervariasi dengan membawa muatan sedimen.

\section{KESIMPULAN}

Laju sedimentasi di Pelabuhan Pulau Baai berkisar 680,60 $\mathrm{mg} / \mathrm{cm}^{2} /$ tahun sampai dengan $49.363,82 \mathrm{mg} / \mathrm{cm}^{2} /$ tahun. Laju sedimentasi tertinggi terdapat di stasiun III yaitu alur pelayaran, sedangkan laju sedimentasi yang paling rendah pada stasiun VI di dekat Muara Sungai. Seluruh tekstur sedimen yang ada di Pelabuhan Pulau Baai adalah pasir.

\section{DAFTAR PUSTAKA}

Barus, B.S. 2013. Keterkaitan Sedimentasi Terhadap Kondisi Ekosistem Terumbu Karang di Perairan Teluk Lampung Provinsi Lampung. Program Studi IImu Kelautan Institut Pertanian Bogor. Tesis (Tidak dipublikasi).

Daulay,B.A. 2014. Karakteristik Sedimen di Perairan Sungai Carang Kota Rebah Kota Tanjung Pinang Provinsi Kepulauan Riau. FIKP UMRAH.

English. S., Wilkison, and V. Baker. 1997.Survey Manual For Tropical Marine Resources. Ed. Ke-2. Australian Intitute Of Marine Science.

Febriyani, A. 2013. Analisis Sedimentasi Yang Terjadi Sekitar Daerah Breakwater Pelabuhan Pulau Baai Bengkulu. FMIPA UNIB. Skripsi 
.Hamdani. 2013. Kajian Teknologi Sand by Passing Penanggulangan Sedimentasi dan Erosi Pantai Bengkulu (Pelabuhan Pulau Baai). Jurnal Ilmu dan Terapan Bidang Teknik Sipil. 19 (1).

Hartoni dan A. Agussalim, 2007. Laju Sedimen Tersuspensi di Wilayah Pembangunan Pelabuhan Tanjung Api-Api Muara Sungai Banyuasin Kabupaten Banyuasin. Jurnal Penelitian Sains. 10 (2) ; 204-211.

Kennish, M.J. 2000. Estuary Restoration and Maintenance: The National Estuary Programme. Boca Raton, USA: CRC Press: 359 pp.

Komar, P. D. 1983. Handbook of Coastal Processes and Erosion. CRC Press, Inc. Boca Raton. Plorida.

Mulyadi. H. Mubarak. D. Yoswaty. 2013. Sebaran Fraksi Sedimen Dasar Permukaan di Perairan Pantai Pulau Topang Provinsi Riau.

PT PELINDO II. 2009. Tak Tuntas Pathaway, Pelindo II Keruk Alur Rakyat Bengkulu. Bengkulu.

Purba, M dan B. Wahyudi. 2003. Atlas Sumber Daya Pesisir Provinsi Bengkulu. Bappeda Provinsi Bengkulu.

Ridho, A. 2005. Pendangkalan Danau dan Waduk: Proses, Konsekwensi dan Penangananya. Jurnal Alami. 10(1) : $14-18$.

Rifardi and Ujiie. 1993. Sedimentological Aspects of the Oura River Estuary and its Environs on the East Coast of Northern Okinawa Island. Bull. Coll. Sci., University Ryukyus, 56: 145 - 163.

Rifardi, Oki and Tomiyasu. 1998. Sedimentary Environment Based on Texture Surface Sediments and Sedimention Rate in South Yatsushiro Kai (Sea), Southwest Kyusu, Japan. Jour. Sedimentol. Soc. Japan. (48): $67-84$.

Rifardi, 2008. Ukuran Butir Sedimen Perairan Pantai Dumai Selat Rupat Bagian Timur Sumatera. Jurnal Ilmu Lingkungan Universitas Riau.

Rifardi, 2012. Edisi Revisi Ekologi Sedimen Laut Modern. UR PRESS; Pekanbaru

Sulistiyo, B., S.N. Muin. 1994. Studi Penentuan Perubahan Garis Pantai Kawasan Kota Madia Bengkulu. Fakultas Pertanian Universitas Bengkulu. 
Supiyati, Suwarsono, dan I. Setiawan. 2009. Angkutan Sedimen Penyebab Pendangkalan Pelabuhan Pulau Baai Bengkulu Dengan Metode Diskritisasi Dinamika Oseonografi. FMIPA. Universitas Bengkulu.

Supiyati, Suwarsono dan K. Hutami. 2012. Pola Arus Pasang Surut di Pelabuhan Pulau Baai Bengkulu Menggunakan Softwere SurfaceWater Modeling System (SMS) 8.1. 8 (2): 792-795

Supiyati. Halauddin, dan G. Arianty. 2012. Karakteristik dan Kualitas Air di Muara Sungai Hitam Provinsi Bengkulu dengan Softwere Som Toolbox 2. Jurnal Ilmu Fisika Indonesia. 1(2)

Triatmodjo, B. 1996. Pelabuhan. Penerbit Beta Offset. Yogyakarta.

Triadmodjo, B. 1999. Teknik Pantai. Offset. Yogyakarta.

Wibowo, Y. A. 2012. Dinamika Pantai (Abrasi dan Sedimentasi). Makalah Gelombang.

Wibisono, MS. 2005. Pengantar IImu Kelautan. PT Gramedia Widiasarana Indonesia. Jakarta. 